UDK 334.75(73)(4-672EU)

Biblid 0543-3657, 72 (2021)

God. LXXII, br. 1182, str. 65-86

Izvorni naučni rad

Primljen: 26.5.2021.

Prihvaćen: 14.6.2021.

doi: https://doi.org/10.18485/iipe_mp.2021.72.1182.3

Miloš SRZENTIĆ ${ }^{1}$

\title{
Strukturne promene u privredama SAD i EU prouzrokovane širenjem klastera
}

\section{SAŽETAK}

Korišćenje mera ekonomske politike, u cilju prevazilaženja posledica Svetske ekonomske krize iz 2007. godine, u dugom roku u privredama SAD i EU pokazalo je različite rezultate u različitim urbanim aglomeracijama. Da bi se sagledali uzroci takvih uticaja primenjenih mera u ovom radu je izvršena analiza funkcionisanja urbanih aglomeracija, sa usmerenjem na određene oblike širenja klastera koji se nalaze u njima. To je izvršeno, pre svega, posredstvom dve osnovne ekonomske velične - nezaposlenosti i BDP-a, čije su promene praćene $u$ njima, tokom posmatranih perioda. Ispitivan je uticaj potencijalnog širenja osnovnog klastera u njima na te ekonomske veličine, čiji je uzajamni odnos posmatran u skladu sa osnovnom hipotezom ovog rada. Na osnovu dobijenih rezultata, formirani su predlozi dodatnih mera strukturne ekonomske politike.

Ključne reči: industrijski klasteri, Okunov koeficijent, strukturna ekonomska politika, širenje klastera

\section{Uvod}

Svetska ekonomska kriza iz 2007. godine imala je negativne posledice na automobilsku industriju SAD, posebno na tri kompanije koje čine Veliku trojku sa sedištem $u$ Detroitu. Neposredno po njenom završetku, konstatovano je da dotadašnji mehanizmi funkcionisanja i širenja Detroitskog klastera ne daju očekivane rezultate $u$ odnosu na optimalne mogućnosti prilikom iskorišćavanja njegovih proizvodnih i tržišnih

\footnotetext{
${ }^{1}$ Doktor ekonomskih nauka. E-mail: srzenticmil@sezampro.rs
} 
kapaciteta. Iz tog razloga javila se potreba za pronalaženjem novih oblika širenja takvih klastera, preko kojih bi došlo do poboljšanja iskorišćavanja i prenošenja načina organizovanja poslovanja u njima, posebno merenih ekonomskim pokazateljima.

Osnovni problem razmatran $u$ ovom radu odnosi se na činjenicu da prilikom pokušaja unapređenja poslovanja u postojećim klasterima, i prilikom osnivanja novih u urbanim aglomeracijama, često ne dolazi do očekivanih poboljšanja ekonomskih rezultata u njima. Iz tog razloga bilo je potrebno pristupiti analizi širenja osnovnog klastera iz polazišne urbane aglomeracije, u kojoj se nalazi osnovni klaster, u ostale odredišne urbane aglomeracije.

Cilj rada je bio pronalaženje predloga za formiranje novih dodatnih mera strukturne ekonomske politike kojima bi se uticalo na buduće koncepte makroekonomskih politika. Na taj način bi se poboljšala ekonomska efikasnost u dugom roku postojećih i novoosnovanih klastera u urbanim aglomeracijama.

Predmet rada je analiza uticaja promene kretanja odnosa kratkoročne nezaposlenosti i dugoročnog BDP-a na poslovanje u posmatranim urbanim aglomeracijama, tokom ukupnog vremenskog perioda od 2006. do 2018. godine. To su osnovne ekonomske veličine ispitivane $\mathrm{u}$ ovom radu, posredstvom kojih se ispoljavaju uticaji primenjenih mera ekonomske politike u tim urbanim aglomeracijama. Ove mere utiču direktno na funkcionisanje posmatranih urbanih aglomeracija i onih klastera koji posluju u njima, a indirektno i na proces širenja klastera. Istraživanje takođe obuhvata analizu uzroka širenja osnovnog klastera, i ispitivanje potencijalnog uticaja takvih promena na početak primene i efikasnost delovanja dodatnih strukturnih mera ekonomske politike.

Metode naučnog istraživanja koje su ovde korišćene su sledeće: Metodom komparativne analize izvršen je uporedni prikaz posmatranog oblika potencijalnog širenja klastera u ovim državama. Metodama kvantitativne i kvalitativne analize izvršeno je ispitivanje prethodno prikupljenih i grupisanih podataka, posebno o promenama u vrednostima nezaposlenosti i BDP-a.

U skladu sa navedenim, osnovna hipoteza koja je bila obuhvaćena istraživanjem sadržanim u ovom radu definisana je kao: što se kratkoročna nezaposlenost $u$ urbanim aglomeracijama više smanjuje to se dugoročni BDP u njima više povećava.

Rezultati istraživanja, koje je prethodilo izradi ovog rada, prikazani su u tri odvojena dela rada na sledeći način. U prvom delu rada prikazani su uzroci strukutrnih promena u privredama koji su uslovljeni širenjem klastera. Drugi deo rada sadrži analizu uticaja potencijalnog širenja klastera na strukturne promene u posmatranim privredama. Ona je sprovedena na primerima privreda SAD, s jedne strane, odnosno Velike Britanije i 
Francuske, s druge strane. Dobijene vrednosti su korišćene pri dokazu osnovne hipoteze od koje se pošlo u istraživanju sadržanom u ovom radu. U trećem delu rada predstavljene su posledice strukturnih promena, koje su uzrokovane širenjem klasera, na privrede SAD i EU.

\section{Definisanje teorijskih pojmova}

Urbane aglomeracije mogu da se definišu kao šire administrativnoteritorijalne jedinice koje obuhvataju ograničen prostor sastavljen od jedne ili više urbanih zona nastalih oko velikih gradova.

$\mathrm{U}$ urbanim aglomeracijama mogu da se formiraju aglomeracije proizvodnje koje su određene ekonomskim faktorima, čije se delovanje ovde ispoljava upravo posredstvom posmatranih ekonomskih veličina: nezaposlenosti i bruto domaćeg proizvoda (BDP).

U aglomeracijama proizvodnje može postepeno da dođe do formiranja klastera. Na osnovu obavljanja primarne aktivnosti u njima, klasteri se mogu podeliti u više grupa. U ovom radu su analizirani industrijski klasteri. Oni se mogu definisati kao grupa poslovnih preduzeća i neposlovnih organizacija za koje je članstvo svakog od njih u toj grupi važan element njihove pojedinačne konkurentnosti. ${ }^{2}$ Klasteri automobilske industrije, čije je poslovanje i širenje u druge aglomeracije proizvodnje analizirano u ovom radu, spadaju upravo u grupu industrijskih klastera.

Na osnovu prioriteta potreba koje bi trebalo da budu zadovoljene može se izdvojiti nekoliko oblika širenja klastera. To su oblici zasnovani na potrebama: 1) za unapređenjem poslovanja širenjem klastera po jednoj istoj, nezavisnoj, fazi poslovanja, ili po više različitih ali sukcesivno zavisnih faza poslovanja; 2) za povećanjem broja kompanija prilikom proširenja u odnosu na broj kompanija u osnovnom klasteru; 3) za proširenjem postojećeg klastera ili stvaranjem novog klastera, i 4) za proširenjem poslovanja osnovnog klastera u domaće ili inostrane zemlje.

U zavisnosti od broja faza poslovanja koje bi mogle da se obavljaju u klasterima, proces njihovog širenja može da se obavlja u dva pravca horizontalno i vertikalno. ${ }^{3}$ Horizontalno širenje klastera zasnovano je na obavljanju jedne iste faze poslovanja $u$ više kompanija koje sačinjavaju taj klaster. Vertikalno širenje klastera zasnovano je na postojanju više različitih faza poslovanja u jednoj kompaniji, koja predstavlja sastavni deo tog klastera.

\footnotetext{
${ }^{2}$ Edward M. Bergman \& Edward J. Feser, Industrial and Regional Clusters: Concepts and Comparative Applications, (1999). Reprint, Edited by Scott Loveridge and Randall Jackson, WVU Research Repository, 2020, p. 8.

${ }^{3}$ Vladimir Grbić, Ekonomija Evropske unije, Megatrend univerzitet primenjenih nauka, Beograd, 2005, str. 150.
} 
Iz ovih razloga, za potrebe analize sadržane $u$ ovom radu, razmatrani klasteri su podeljeni u tri grupe i definisani na sledeći način. Osnovni klaster je klaster u kome, još iz prethodnih vremenskih perioda, sve kompanije koje ulaze u njegov sastav obavljaju privredne aktivnosti u svim fazama poslovanja i koji započinje proces širenja. Transplant klaster je klaster koji nastaje prenošenjem iz osnovnog klastera privrednih aktivnosti svih kompanija koje odgovaraju svim fazama poslovanja. Izvedeni klaster je klaster koji nastaje prenošenjem iz osnovnog klastera privrednih aktivnosti jedne kompanije koje odgovaraju jednoj fazi poslovanja.

Ekonomske veličine čije je kretanje posebno praćeno u ovom radu su nezaposlenost i BDP.

Nezaposlenost je u SAD praćena preko ukupnog broja nezaposlenih osoba tokom posmatranih vremenskih perioda. Nezaposlene osobe definisane su kao one osobe koje nisu imale posao u toku referentne nedelje. One su aktivno tražile posao u odgovarajućem periodu koji je prethodio referentnoj nedelji, u toku kojeg su bile sposobne za rad.

Kao procentualni pokazatelj nezaposlenosti korišćena je stopa nezaposlenosti. Ona je definisana kao broj nezaposlenih osoba procentualno izražen u radnoj snazi, dok radnu snagu predstavlja zbir zaposlenih i nezaposlenih osoba. ${ }^{4}$

BDP je definisan kao vrednost svih finalnih proizvoda i usluga proizvedenih na teritoriji jedne države, bez obzira da li su ih proizveli rezidenti te ili neke inostrane države. ${ }^{5}$ Za njegov prikaz u ovom radu u SAD korišćen je realni BDP, čija je vrednost prilagođena promeni u cenama za posmatrani vremenski period. ${ }^{6}$

Kao procentualni pokazatelj BDP-a korišćena je stopa BDP-a. Ona je ovde definisana kao godišnja procentualna promena u vrednosti realnog BDP-a.

Kretanje stope BDP-a i stope nezaposlenosti u urbanim aglomeracijama u ovom radu posebno je praćeno na primeru urbanih aglomeracija u SAD. Za prikaz urbanih aglomeracija u SAD korišćene su metropoliten statističke zone. $^{7}$

\footnotetext{
${ }^{4}$ Bureau of Labor Statistics, Metropolitan Area Employment and Unemployment - May 2020, News Release, USDL-20-1309, U.S. Department of Labor, Washington D.C., USA, 1 July 2020, Internet, http://www.bls.gov/news.release/archives/srgune_02262016.pdf, 15/12/2020, p. 5.

${ }^{5}$ Dragana Gnjatović, Osnovi makroekonomije, Megatrend univerzitet primenjenih nauka, Beograd, 2003, str. 16.

${ }^{6}$ Bureau of Economic Analysis, Gross Domestic Product by Metropolitan Area, 2017, News Release, BEA 18-46, U.S. Department of Commerce, Washington D.C., USA, 18 September 2018, Internet, https:/ / www.bea.gov/system/files/2018-09/gdp_metro0918_0.pdf, 12/12/ 2020, p. 4.

${ }^{7}$ Za definisanje urbanih aglomeracija u SAD je korišćena metodologija Cenzus biroa SAD. 68 Internet, https://www.census.gov/programs-surveys/metro-micro/about.html, 16/04/2021.
} 
Osnovna ekonomska relacija kojom se razmatraju odnosi nezaposlenosti i BDP-a definisana je Okunovim zakonom. Oblik Okunovog zakona pomoću koga je u ovom radu analizirano kretanje posmatranih veličina zasniva se na korelaciji da je za svako smanjenje nezaposlenosti u iznosu od jednog procenta potrebno povećanje realnog BDP-a u iznosu od tri procenta. Na osnovu ove teorijske postavke ispitivana je međuzavisnost periodičnih promena u visini njihovih vrednosti u posmatranim urbanim aglomeracijama.

Stavljanjem u procentualni odnos, analogno postavkama Okunovog zakona, posmatrano kretanje nezaposlenosti i BDP-a može se predstaviti preko Okunovog koeficijenta. Ovaj koeficijent pokazuje odnos koji se dobija kao rezultat uticaja jednoprocentne promene realnog BDP-a na stopu nezaposlenosti. ${ }^{8}$ Standardna vrednost Okunovog koeficijenta iznosi -3, što je u skladu sa navedenim teorijskim postavkama Okunovog zakona.

Strukturna ekonomska politika, koja je posebno analizirana u ovom radu, uz tekuću ekonomsku politiku predstavljaju ukupnu ekonomsku politiku. Mere strukurne ekonomske politike predstavljaju deo mera ukupne ekonomske politike čija primena ima za cilj da utiče na strukturne promene u privredi.

Kao i ukupna ekonomska politika, strukturna ekonomska politika može da obuhvata makroekonomsku i mikroekonomsku politiku. Osnovna stukturna makroekonomska politika, analizirana u ovom radu, odnosila se na politiku tržišta kapitala i politiku tržišta rada.

Osnovna strukturna mikroekonomska politika, takođe analizirana $u$ ovom radu, odnosila se na tehnološku politiku i politiku konkurencije.

\section{Uzroci strukturnih promena u privredama $S A D$ i EU određeni širenjem klastera}

U ovom delu radu je, kao jedan od osnovnih mogućih uzroka strukturnih promena u privredama SAD i EU, prikazan uticaj potencijalnog širenja klastera. Razlog tome je što upravo u zavisnosti od odabira različitih oblika širenja klastera dolazi do različitih strukturnih promena u privredama. Za potrebe analize predmeta ovog rada posebno se može istaći oblik širenja osnovnog klastera: u domaćoj zemlji i u inostranoj zemlji.

Kao osnovni klaster izdvojen je klaster automobilske industrije sa sedištem u gradu Detroitu (SAD), koji se naziva i Detroitski klaster. Potencijalno širenje osnovnog klastera $u$ domaćoj zemlji posmatrano je

${ }^{8}$ Laurence Ball, Daniel Leigh \& Prakash Loungani, Okun's Law: Fit at 50?, IMF Working Paper, WP/13/10, International Monetary Fund, Research Department, January 2013, Internet, https://www.imf.org/en/Publications/WP/Issues/2016/12/31/Okun-s-Law-Fit-at-5040236, 29/08/2020, p. 3 . 
upravo na primeru širenja Detroitskog klastera u SAD, dok je širenje osnovnog klastera $u$ inostranoj zemlji posmatrano na primeru širenja Detroitskog klastera u EU. Kao zemlje članice EU, koje bi bile odredišta potencijalnog širenja Detroitskog klastera, posebno su analizirane Velika Britanija i Francuska. ${ }^{9}$

\section{Širenje Detroitskog klastera u domaćoj zemlji}

Detroitski klaster se nalazi u urbanoj aglomeraciji Detroit-VorenDirborn, smeštenoj u saveznoj američkoj državi Mičigen. Ovaj klaster obuhvata automobilske kompanije Dženeral Motors, Ford i Krajsler. Ove tri kompanije su ujedno i tri najveća proizvođača automobila u SAD, a zajedno posmatrano one predstavljaju horizontalni lanac poslovanja. One čine Veliku trojku američke automobilske industrije, a njihova poslovna sedišta i osnovni proizvodni kapaciteti su grupisani u jedan, ovde analizirani, Detroitski klaster.

Osnovna podela posla u svakoj od tih kompanija može se izvršiti u zavisnosti od toga da li se u njima obavljaju: pripreme za istovar sirovina ili utovar finalnih proizvoda $\mathrm{u}$ cilju njihovog transporta ili proizvodnja poluproizvoda, odnosno finalnih proizvoda.

Samim time, u svakoj pojedinačnoj kompaniji mogu da se obavljaju različite, ali međusobno zavisne, privredne aktivnosti u sukcesivnim fazama poslovanja koje zajedno posmatrano predstavljaju vertikalni lanac poslovanja. ${ }^{10}$

Detroitski klaster je već postojeći klaster, sa sedištem u jedinstvenoj aglomeraciji proizvodnje, a ukupan broj kompanija koje ulaze u njegov sastav mogao bi da ostane nepromenjen prilikom njegovog širenja u nove aglomeracije proizvodnje.

Ako se pretpostavi da u urbanoj aglomeraciji Detroit-Voren-Dirborn sve tri kompanije Velike trojke obavljaju po sve tri faze poslovanja, onda se razmatrani oblik širenja osnovnog klastera u domaćoj zemlji može grafički predstaviti matricom 3×3, kao što je i prikazano na Grafikonu 1.

${ }^{9}$ Velika Britanija je u tom periodu bila punopravna članica EU, a ovu integraciju je zvanično napustila 01. februara 2020 godine.

${ }^{10} \mathrm{ILO}$, The future of work in the automotive industry: The need to invest in people's capabilities and decent and sustainable work, Issues paper for the Technical Meeting on the Future of Work in the Automotive Industry, (Geneva, 15-19 February 2021), TMFWAI/2021, International Labour Organization, Sectoral Policies Department, Geneva, 2020, Internet, https://www. ilo.org/wcmsp5/groups/public/ --ed_dialogue/ - -sector/documents/meeting 70 document/wcms_741659.pdf, 19/03/2021, p. 5. 
Grafikon 1: Potencijalni pravci širenja Detroitskog klastera u domaćoj zemlji

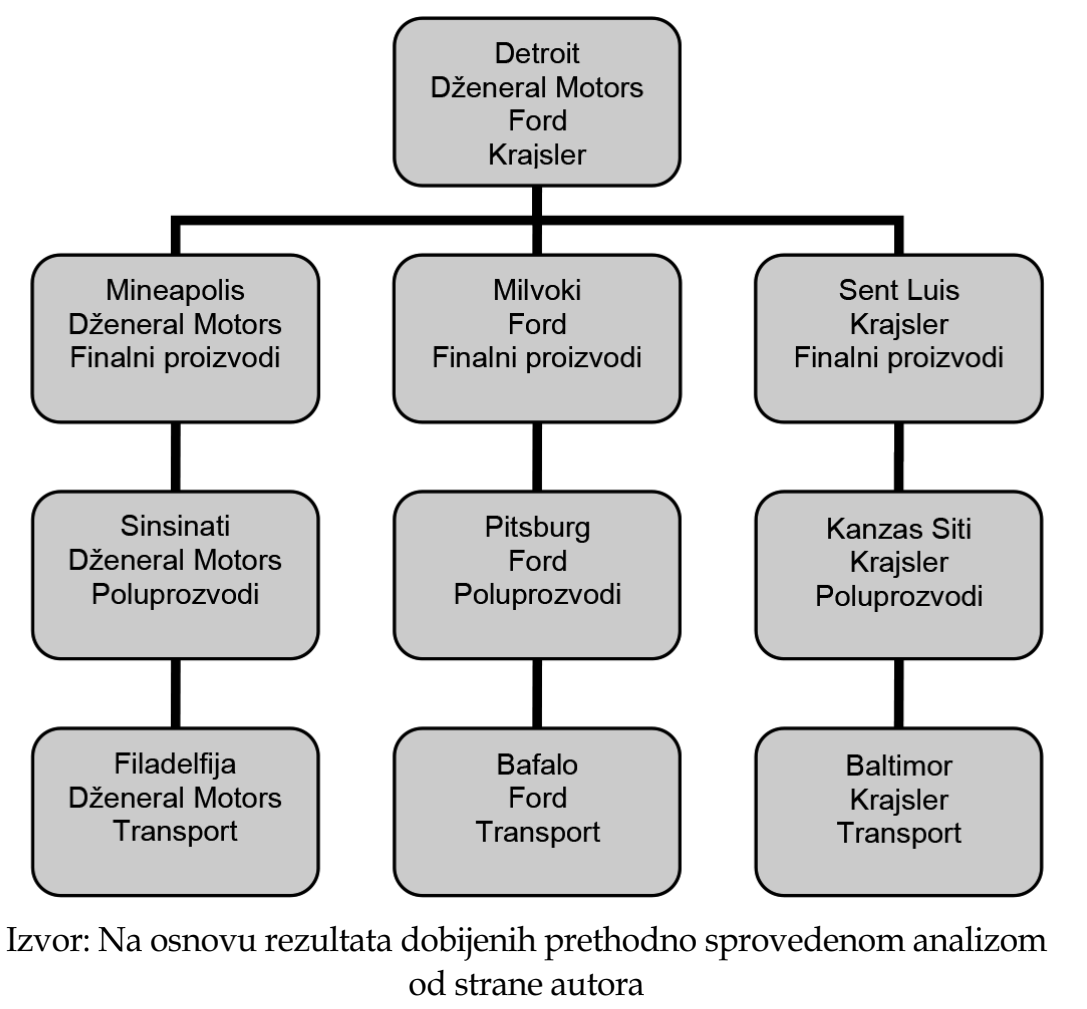

Osnovni kriterijum prilikom izbora potencijalnih pravaca širenja Detroitskog klastera bio je da su to urbane aglomeracije koje već poseduju potrebnu opštu proizvodnu i transportnu infrastrukturu. Uslov da neke urbane aglomeracije postanu odredišne urbane aglomeracije za širenje Detroitskog klastera predstavljao je i broj stanovnika u njima, kao i potrebne stručne kvalifikacije stanovništva. Potrebno je da su to velike urbane aglomeracije u kojima živi i radi u proseku više od milion ljudi koji poseduju odgovarajuće obrazovanje i obuku, što posebno omogućava jednostavniju i bržu geografsku i profesionalnu mobilnost radne snage. Takođe, kriterijum se dodatno odnosio na postojanje, iz prethodnih vremenskih perioda, proizvodnih kapaciteta $\mathrm{u}$ odredišnim urbanim aglomeracijama upravo kompanija automobilske industrije Velike trojke iz Detroitskog klastera.

Upravo se na osnovu ove matrice može teorijski objasniti proces prenošenja poslovanja automobilskih kompanija Velike trojke iz Detroitskog klastera u devet nezavisnih urbanih aglomeracija. Samim time, Detroitski klaster, koji spada u grupu industrijskih klastera, na taj način mogao bi da se 
proširi na teritoriju najmanje sedam različitih saveznih američkih država, $u$ kojima se nalaze sedišta tih urbanih aglomeracija. Industrijski klasteri ne moraju da se nalaze samo na jednoj određenoj geografskoj oblasti, već mogu da obuhvataju celokupne teritorije $u$ regionalnim ili nacionalnim granicama. ${ }^{11}$

Širenje klastera ne zavisi samo od odluka osnovnih klastera, već takođe od odluka vlada država u kojima se nalaze sedišta osnovnih klastera. Razlozi za donošenje takvih odluka vlada država o primeni ekonomskih mera usmerenih na širenje klastera u SAD-u mogu se videti iz sledećeg.

Procenat iskorišćenosti proizvodnih kapaciteta u oblasti automobilske industrije je u proseku na nivou SAD, tokom posmatranog perioda od 2006. do 2018. godine, iznosio $72 \%$. To je statistički značajno manje nego procenat iskorišćenosti proizvodnih kapaciteta ukupne industrijske proizvodnje i prerađivačke proizvodnje, tokom istog vremenskog peroda. ${ }^{12}$ Upravo kao jedan od načina da bi se uticalo na promenu ovakvih privrednih kretanja potrebno je da vlade država mogu da usmere mere strukturne makroekonomske politike, a ovde posebno mere politike tržišta kapitala, na organizovanje razmatranih oblika proizvodnje $u$ aglomeracijama proizvodnje i klasterima, čime dolazi i do promena u strukturi privrede.

Vlade SAD izdvajaju značajna godišnja finansijska sredstva posebno i za mere tehnološke politike usmerene na podršku sektora istraživanja i razvoja, od čega se jedan deo tih sredstava odnosi na podržavanje uslova za širenje klastera. Upravo potreba za transferom tehnologije iz osnovnog Detroitskog klastera $\mathrm{u}$ druge aglomeracije i klastere $\mathrm{u}$ njima, $\mathrm{u}$ domaćoj i inostranim zemljama, a što dovodi do pozitivnog uticaja na sektore istraživanja i razvoja u njima, predstavlja jedan od direktnih uzroka za pristupanje razmatranom procesu širenja klastera. ${ }^{13}$

${ }^{10} \mathrm{ILO}$, The future of work in the automotive industry: The need to invest in people's capabilities and decent and sustainable work, Issues paper for the Technical Meeting on the Future of Work in the Automotive Industry, (Geneva, 15-19 February 2021), TMFWAI/2021, International Labour Organization, Sectoral Policies Department, Geneva, 2020, Internet, https://www.ilo.org/wcmsp5/groups/public/---ed_dialogue/---sector/documents/ meetingdocument/wcms_741659.pdf, 19/03/2021, p. 5.

${ }^{11}$ Raj Nallari \& Breda Griffith, Clusters of Competitiveness, Directions in Development, Private Sector Development, International Bank for Reconstruction and Development / The World Bank, Washington D.C., 2013, Internet, https://openknowledge.worldbank.org/bitstream /handle/10986/15788/79892 0PUB0Clus 00Box377374B00PUBLIC0.pdf?sequence=1\&is Allowed=y, 24/11/2020, p. 113.

${ }^{12}$ Federal Reserve, Industrial Production and Capacity Utilization, Statistical release, G.17 (419), Board of Governors of The Federal Reserve System, Washington D.C., USA, 15 December 2020, Internet, https:/ / www.federalreserve.gov/releases/G17/20201215/g17.pdf, 14/04/ 2021, p. 14.

${ }^{13}$ OECD (2014), OECD Economic Surveys: United States 2014, OECD Publishing, Paris, june 2014, Internet, https:/ / dx.doi.org/10.1787/eco_surveys-usa-2014-en , 11/04/2021, p. 52. 
Širenje Detroitskog klastera u inostranim zemljama

Za razliku od oblika širenja osnovnog Detroitskog klastera u SAD, njegovo širenje u nekoj inostranoj zemlji podrazumevalo bi prvo formiranje transplant klastera u odredišnoj aglomeraciji u toj inostranoj zemlji. Ovaj transplant klaster bi mogao tek onda da se širi u toj inostranoj zemlji, analogno širenju osnovnog Detroitskog klastera u SAD.

Novi transplant klaster $\mathrm{u}$ Velikoj Britaniji mogao bi da se nalazi $\mathrm{u}$ urbanoj aglomeraciji Mančester, a sadržao bi poslovne filijale sve tri kompanije Velike trojke iz SAD. Kao primer za potencijalnu lokaciju jednog od izvedenih klastera, u kome bi se obavljala faza poluproizvodnje, mogla bi da se izdvoji urbana aglomeracija oko grada Šefilda. Za ovu aglomeraciju je posebno karakteristična proizvodnja i obrada čelika, kao osnova za stvaranje poluproizvoda neophodnih za nesmetano funkcionisanje automobilske industrije.

U cilju podržavanja uslova za širenje klastera, u aprilu 2013. godine, vlada Velike Britanije povećala je gornju granicu, u visini od $10 \%$ iznad maksimalno dozvoljene sume, finansijskih sredstava koja mogu da se pozajme za unapređenje poslovanja sektora istraživanja i razvoja velikih preduzeća, koja posluju upravo grupisana $\mathrm{u}$ klastere $\mathrm{u}$ aglomeracijama proizvodnje.

Bilo je planirano da se ova granica sredstava namenjenih subvencionisanju mera tehnološke politike poveća na $11 \%$ od aprila 2015 . godine. ${ }^{14}$

Novi transplant klaster u Francuskoj mogao bi da se nalazi u urbanoj aglomeraciji Marsej, koji bi takođe sadržao poslovne filijale sve tri kompanije Velike trojke iz SAD.

Kao primer za formiranje izvedenog klastera, u kome bi se odvijala faza poluproizvodnje, mogla bi da se izdvoji urbana aglomeracija oko grada Liona. Za ovu aglomeraciju je takođe posebno karakteristična proizvodnja i prerada čelika koji se koriste u proizvodnji automobila.

U istom periodu, u 2013. godini, vlada Francuske je pristupila izmeni načina finansiranja državnih subvencija usmerenih povećanju konkurentnosti poslovanja klastera $\mathrm{u}$ aglomeracijama proizvodnje. U cilju povećanja efikasnosti tih mera strukturne politike, određen je konačni rok za primenu državnih subvencija, za koje je planirano da postepeno budu zamenjene privatnim izvorima finansiranja. Iz tog razloga je u 2015. godini takvo smanjenje državnih subvencija, namenjenih upravljačkim odborima klastera, uslovljeno realizovanjem naučnoistraživačkih projekata i učešćem privatnih u državnom izvoru finansiranja tih projekata. ${ }^{15}$

${ }^{14}$ OECD (2015), OECD Economic Surveys: United Kingdom 2015, OECD Publishing, Paris, february 2015, Internet, https://dx.doi.org/10.1787/eco_surveys-gbr-2015-en , 17/04/2021, p. 53.

${ }^{15}$ OECD (2015), OECD Economic Surveys: France 2015, OECD Publishing, Paris, march 2015, Internet, http://dx.doi.org/10.1787/eco_surveys-fra-2015-en , 27/04/2021, p. 57. 
Ovakve moguće promene $u$ načinima proizvodnje izazvane potencijalnim širenjem klastera na nivou urbanih aglomeracija utiču posledično i na takve promene na nivou čitavih posmatranih privreda, odnosno dovode do strukturnih promena u njima. Upravo takav uticaj potencijalnog širenja klastera na organizovanje načina proizvodnje predstavlja osnovni razmatrani uzrok strukutrnih promena u privredama SAD i EU.

\section{Analiza uticaja širenja klastera na strukturne promene u privredama SAD $i$ EU tokom posmatranog perioda}

Postupak sprovedene analize uticaja potencijalnog širenja klastera na strukturne promene u privredama SAD i EU može da se predstavi na sledeći način.

Uticaj primene razmatranih oblika širenja klastera može da se predstavi preko promena u kretanjima analiziranih ekonomskih veličina nezaposlenosti i BDP-a u posmatranim urbanim aglomeracijama. Kvantifikacija promena ovih analiziranih ekonomskih veličina može da se izrazi preko Okunovog koeficijenta. Poređenjem dobijenih vrednosti tog koeficijenta sa standardnom vrednošću Okunovog koeficijenta, mogu da se odrede njihova odstupanja od te standardne vrednosti Okunovog koeficijenta. Ukoliko su ta odstupanja od standardne vrednosti posmatranog koeficijenta statistički značajna, može se konstatovati da postoje razlozi za početak primene širenja klastera po analiziranim oblicima u posmatranim privredama.

Odnosi nezaposlenosti i BDP-a posmatrani su kako na nivoima urbanih aglomeracija tako i na nivoima ukupnih privreda.

Prvo su u jednom vremenskom periodu posmatrana dva načina grupisanja urbanih aglomeracija, koji se međusobno razlikuju u zavisnosti od broja pojedinačnih aglomeracija koje ulaze u njihov sastav. Prema prvom načinu, posmatrane urbane aglomeracije mogu da se podele $u$ tri grupe od po tri aglomeracije. Prema drugom načinu, posmatrane urbane aglomeracije mogu da se svrstaju u jednu grupu od ukupno devet aglomeracija.

Ukupan posmatrani vremenski period bio je od 2006. do 2018. godine. $\mathrm{U}$ tom periodu je, prema korišćenim empirijskim podacima, $\mathrm{u}$ aglomeraciji Detroit-Voren-Dirborn prosečan odnos nezaposlenosti i BDP-a, izražen preko Okunovog koeficijenta, iznosio -1,21.

Prvi način grupisanja urbanih aglomeracija, sa po tri odredišne aglomeracije u svakoj grupi, predstavljen je u matrici prikazanoj na Grafikonu 1. Stavljanjem odgovarajućih empirijskih podataka u matricu sa Grafikona 1 i razvijanjem te matrice po njenom horizontalnom i vertikalnom pravcu može se konstatovati sledeće.

Razvijanjem te matrice po njenom horizontalnom pravcu, posmatrane urbane aglomeracije su svrstane $u$ tri grupe. Samim time, u svakoj 
pojedinačnoj grupi tih aglomeracija, posmatrano preko horizontalnog pravca, po sve tri kompanije iz Detroitskog klastera mogu da obavljaju po jednu različitu fazu poslovanja.

Kao primer toga može da se posmatra grupa od tri urbane aglomeracije svrstane zajedno prema jednoj od faza poslovanja, a koju čine aglomeracije sa sedištima u gradovima Sinsinati, Pitsburg i Kanzas Siti. Ovu grupu aglomeracija čine klasteri proizvođača poluproizvoda, a promene u kretanju odnosa stopa rasta realnog BDP-a i stopa nezaposlenosti u njima su prikazane na Grafikonu 2. Vrednost Okunovog koeficijenta u proseku za ovu grupu aglomeracija, u posmatranom periodu od 2006. do 2018. godine, iznosi $-0,64$. U poređenju sa ostale dve grupe aglomeracija, koje čine proivođači finalnih proizvoda i preduzeća koja obavljaju poslove transporta, ova grupa aglomeracija ima prosečnu vrednost Okunovog koeficijenta najbližu njegovoj standardnoj vrednosti, $\mathrm{u}$ istom posmatranom periodu.

Grafikon 2: Promene u kretanju odnosa stopa nezaposlenosti i stopa rasta realnog BDP-a u posmatranim urbanim aglomeracijama u periodu od 2006. do 2018. godine

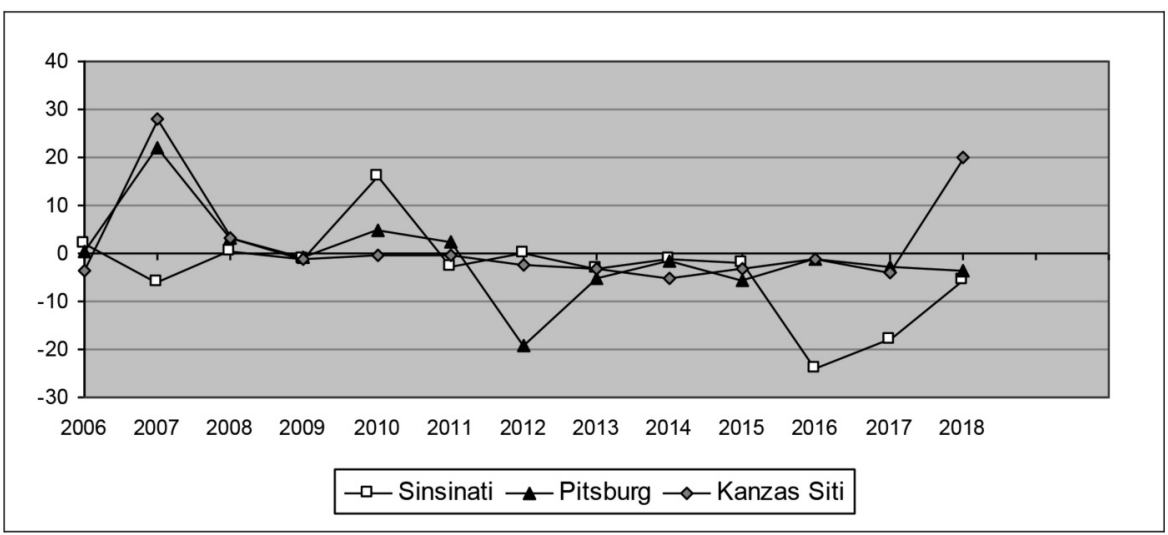

Izvor: Kalkulacije autora na osnovu podataka iz: Bureau of Labor Statistics, Internet, https:/ / www.bls.gov/bls/news-release/metro.htm, 16/02/2021 i Bureau of Economic Analysis, Internet, https://www.bea.gov/data/gdp/gdpcounty-metro-and-other-areas, 14/02/2021.

Posmatrano sa druge strane, primenom metoda komparativne analize može se videti da je odstupanje od standarne vrednosti Okunovog koeficijenta u aglomeraciji Detroit-Voren-Dirborn dvostruko manje nego odstupanje od njegove standardne vrednosti u grupi aglomeracija Sinsinati, Pitsburg i Kanzas Siti.

Razvijanjem te matrice po vertikalnom pravcu, posmatrane urbane aglomeracije mogu da se svrstaju takođe u tri grupe. Samim time, u svakoj 
pojedinačnoj grupi aglomeracija, posmatrano preko vertikalnog pravca, po sve tri faze poslovanja bi mogla da obavlja po jedna određena kompanija iz posmatranog Detroitskog klastera.

Drugi način grupisanja posmatranih aglomeracija je formiranje jedne grupe od svih devet posmatranih odredišnih aglomeracija sa izvedenim klasterima u njima. Kretanje empirijskih podataka u ovoj grupi aglomeracija, koju čini svih devet aglomeracija iz matrice sa Grafikona 1, predstavljeno je preko proseka vrednosti posmatranih ekonomskih veličina u njima. Taj prosek, izražen preko Okunovog koeficijenta, u periodu od 2006. do 2018. godine iznosio je 0,26 . Njegova pozitivna vrednost pokazuje da prosečno godišnje kretanje nezaposlenosti i BDP-a, u posmatranih devet aglomeracija u tom periodu, ne podržava osnovnu postavku Okunovog zakona o inverznom odnosu te dve ekonomske veličine.

Zatim su posmatrane obe grupe urbanih aglomeracija $\mathrm{u}$ nekoliko različitih vremenskih perioda.

Kretanje nezaposlenosti i BDP-a u grupi aglomeracija Sinsinati, Pitsburg, Kanzas Siti je, pored analiziranog ukupnog vremenskog perioda od 2006. do 2018. godine, posmatrano i u periodima od 2008. do 2011. godine i od 2008. do 2015. godine. Prvi period 2008-2011. godine predstavlja kratak rok, a obuhvata period od ukupno četiri godine. Drugi period 2008-2015. godine predstavlja dugi rok, jer se njegovo trajanje sastoji od dva uzastopna kratka roka, a obuhvata period od ukupno osam godina.

$\mathrm{Na}$ osnovu dobijenih rezultata može se konstatovati da je $u$ posmatranom kratkom roku, s obzirom na pozitivnu vrednost Okunovog koeficijenta, došlo do narušavanja inverznog odnosa $u$ kretanju nezaposlenosti i BDP-a, usled ubrzanog rasta nezaposlenosti. Time je došlo do odstupanja od osnovnih postavki Okunovog zakona.

Međutim, već sa primenom mera tekuće i strukturne makroekonomske politike došlo je u dugom roku do ponovnog uspostavljanja inverznog odnosa u kretanju ovih veličina, a time i do negativne vrednosti Okunovog koeficijenta. ${ }^{16}$

Iste tendencije $\mathrm{u}$ kretanju nezaposlenosti i BDP-a mogu se primetiti i prilikom poređenja vrednosti Okunovog koeficijenta u drugoj posmatranoj grupi od devet aglomeracija.

Na osnovu tako dobijenih odnosa pristupilo se dokazu osnovne hipoteze ovog rada.

\footnotetext{
${ }^{16}$ European Economy, The EU's response to support the real economy during the economic crisis: An overview of Member States' recovery measures, Occasional Papers No 51, European Commission, Directorate-General for Economic and Financial Affairs, July 2009, Internet, https://ec.europa.eu/economy_finance/publications/pages/publication_summary15670_ en.htm, 19/02/2021, p. 15.
} 
$\mathrm{U}$ obe, ovde posmatrane, grupe urbanih aglomeracija u dugom roku, odnosno u periodu od 2008. do 2015. godine, vrednosti Okunovog koeficijenta bile su negativne, čime su odražavale navedene postavke Okunovog zakona. Ujedno, to su one posmatrane urbane aglomeracije u kojima je vrednost Okunovog koeficijenta $\mathrm{u}$ dugom roku bila bliža standardnoj vrednosti tog koeficijenta nego njegova vrednost $\mathrm{u}$ kratkom roku.

Time se na indirektan način, posmatrajući iz suprotnog smera, dolazi do potrebnog dokaza osnovne hipoteze rada. S obzirom na to da je istraživanje obuhvatalo praćenje kretanja nezaposlenosti i BDP-a, do uspostavljanja razmatranih inverznih odnosa između te dve ekonomske veličine u dugom roku, koji odgovaraju postavkama Okunovog zakona, nije moglo da dođe bez prethodnog dovoljnog smanjenja nezaposlenosti u kratkom roku koje je prouzrokovalo povećanje BDP-a u dugom roku. Upravo ova, poslednje navedena, međuzavisnost ove dve posmatrane ekonomske veličine predstavlja predmet ispitivanja osnovne hipoteze ovog rada.

Odnosno, ne bi bilo moguće formiranje inverznog odnosa nezaposlenosti i BDP-a, predstavljenog preko Okunovog koeficijenta, da nije prethodno postojala odgovarajuća međuzavisnost u kretanju nezaposlenosti u kratkom roku i BDP-a u dugom roku.

Na osnovu svega navedenog do sada, može se konstatovati da rezultati dobijeni gore sprovedenom analizom kretanja vrednosti Okunovog koeficijenta, $\mathrm{u}$ određenim posmatranim urbanim aglomeracijama, predstavljaju upravo potvrdu osnovne hipoteze od koje se pošlo u istraživanju sadržanom u ovom radu.

Posle toga, dobijene vrednosti Okunovog koeficijenta $u$ urbanim aglomeracijama su upoređivane sa odgovarajućim vrednostima tog koeficijenta na nivoima saveznih američkih država u kojima se nalaze sedišta tih aglomeracija i na federalnom nivou SAD, tokom ukupnog posmatranog perioda od 2006. do 2018. godine.

Na osnovu toga se može primetiti sledeće:

Prosečna vrednost Okunovog koeficijenta na nivou sedam posmatranih saveznih država je tokom tog perioda, kao i u grupi od devet posmatranih urbanih aglomeracija, takođe odstupala od postavki Okunovog zakona. Međutim, za razliku od prosečne vrednosti Okunovog koeficijenta na nivou tih saveznih država, vrednost Okunovog koeficijenta na federalnom nivou SAD u posmatranom periodu jeste bila u skladu sa postavkama Okunovog zakona, ali je iznosila dva i po puta manje od njegove vrednosti $u$ aglomeraciji Detroit-Voren-Dirborn $\mathrm{u}$ istom periodu.

Kretanja nezaposlenosti i BDP-a, izražena preko vrednosti Okunovog koeficijenta, takođe su praćena kako na nivoima pojedinačnih država članica EU, kao što su u ovom radu posmatrane Velika Britanija i Francuska, tako i na nivou EU kao celine. U Velikoj Britaniji je u posmatranom periodu od 2006. do 2018. godine prosečna vrednost Okunovog koeficijenta iznosila 0,1. 
U Francuskoj je tokom istog posmatranog perioda prosečna vrednost Okunovog koeficijenta iznosila $-0,48 \cdot{ }^{17} \mathrm{Na}$ nivou EU prosečna vrednost ovog koeficijenta, takođe u periodu od 2006. do 2018. godine, bila je još bliža standardnoj vrednosti Okunovog koeficijenta nego vrednosti tog koeficijenta na nivou Velike Britanije i Francuske u istom posmatranom periodu.

Međutim, s obzirom na to da još uvek postoji značajno odstupanje od standardne vrednosti Okunovog koeficijenta, kako na nivou privrede SAD tako i na nivoima privreda Velike Britanije i Francuske, odnosno EU kao celine, može se konstatovati da postoji potreba za primenom razmatranog oblika širenja osnovnog klastera. To bi dovelo upravo do odgovarajućih strukturnih promena u privredama posmatranih zemalja.

\section{Posledice strukturnih promena na privrede $S A D$ i EU prouzrokovane širenjem klastera}

Na isti način kao i uzroci strukturnih promena, posredstvom potencijalne primene razmatranog oblika širenja klastera, i posledice strukturnih promena mogu se posmatrati sa stanovišta domaćih i inostranih privreda.

Posledice strukturnih promena posmatrane sa stanovišta domaćih privreda mogu da se prikažu na sledeći način.

Efekti primenjenih tekućih i strukturnih makroekonomskih mera omogućavaju odgovarajuću realizaciju primene procesa širenja klastera, a pravci njihovog dejstva su istovrsni sa ciljevima pravaca tog procesa širenja klastera. Ove makroekonomske mere obuhvataju mere politike tržišta rada koje su usmerene na već postojeće aglomeracije proizvodnje i sva preduzeća koja, grupisana u izvedene klastere, posluju u njima. ${ }^{18}$ Takođe, ove makroekonomske mere obuhvataju i mere tržišta kapitala koje su usmerene na međusobno usklađivanje poslovanja između osnovnog i izvedenih klastera.

Posledice strukturnih promena prouzrokovanih razmatranim širenjem klastera dovode do prostornog razmeštanja postojećih industrijskih kapaciteta preduzeća i njihovog grupisanja na novim lokacijama u obliku klastera unutar aglomeracija proizvodnje.

Ova klasifikacija uticaja strukturnih promena izvršena je prema kriterijumu lokacije industrijskih kapaciteta preduzeća. S jedne strane

${ }^{17}$ Za dobijanje posmatranih vrednosti Okunovog koeficijenta su korišćeni podaci iz baze podataka OECD-a, Internet, https:// stats.oecd.org/index.aspx?queryid=60702\#, 02/04/2021.

${ }^{18}$ André Gama, Catherine Saget \& François Eyraud, Inventory of labour market policy measures in the EU 2008-13: The crisis and beyond, Synthesis Report, International Labour Organization, International Labour Office, Research Department, Geneva, 2015, Internet, https://www.ilo. org/wcmsp5/groups/public/ --dgreports/ - -inst/documents/publication/wcms_

78 436119.pdf, 15/04/2021, p. 18. 
posmatrano, takva alokacija određenog broja industrijskih kapaciteta iz iste faze poslovanja, iz jedne $u$ više različitih urbanih aglomeracija, dovodi do promena u strukturi privrede. Posmatrano s druge strane, formiranje u svakoj odredišnoj urbanoj aglomeraciji novog poslovnog centra ne mora da bude samo od značaja za osnovni klaster iz oblasti automobilske industrije. Stvaranjem potrebne prateće infrastrukture i uslova za privlačenja podizvođača mogu da se stvore uslovi za prostornu koncentraciju industrijskih kapaciteta iz iste faze poslovanja od klastera drugih proizvođača. ${ }^{19}$

Da bi se uticalo na povećanje obima iskorišćavanja tih industrijskih kapaciteta i efikasnosti upotrebe raspoloživih faktora proizvodnje, koji se nalaze $\mathrm{u}$ posmatranim aglomeracijama, potrebno je da se primene dodatne mere politike tržišta kapitala. Istovremeno, od posebnog značaja za poslovanje razmatranih aglomeracija proizvodnje i donošenje odluka o izboru oblika i početku procesa širenja klastera mogu da se izdvoje one dodatne mere politike tržišta rada koje se odnose na sprovođenje geografske i profesionalne mobilnosti radne snage. ${ }^{20} \mathrm{Na}$ taj način dolazi do skraćenja vremena, a time i troškova, potrebnih za preseljenje i prekvalifikaciju radne snage.

Efekti primene strukturnih mera mikroekonomske politike, koje su neposredno prethodile širenju klastera, mogu da dovedu do unapređenja tehnoloških karakteristika proizvoda preduzeća koja u njima posluju. Takođe, ove mere mogu da dovedu do uspostavljanja odgovarajućih konkurentskih odnosa između preduzeća koja posluju u posmatranim klasterima.

Posledice strukturnih promena, prouzrokovanih takvim širenjem klastera, dovode do diversifikacije poslovanja pojedinačnih preduzeća u postojećim klasterima i specijalizacije poslovanja u preduzećima prilikom osnivanja novih izvedenih klastera. ${ }^{21}$ Ova klasifikacija uticaja strukturnih promena izvršena je prema kriterijumu funkcije poslovnih aktivnosti $u$ industrijskim kapacitetima preduzeća.

Da bi se uticalo na povećanje efikasnosti obavljanja tih poslovnih aktivnosti mogu da se primene sledeće dodatne mere strukturne mikroekonomske politike: 1) Mere tehnološke politike koje su usmerene ka

${ }^{19}$ Raj Nallari, Breda Griffith \& Shahid Yusuf, Geography of Growth: Spatial Economics and Competitiveness, Directions in development, Infrastructure, 68360, International Bank for Reconstruction and Development / The World Bank, 2012, Internet, https:/ /openknow ledge.worldbank.org/bitstream/handle/10986/6020/683600PUB0EPI0067902B0978082139 4861.pdf? sequence=1\&isAllowed=y, 15/01/2021, p. 6 .

${ }^{20}$ Brian Snowdon \& Howard R.Vane, Modern macroeconomics, Its origin, development and current state, Edward Elgar, Cheltenham, UK - Northampton, MA, USA, 2005, p. 187.

${ }^{21}$ Eurostat, Eurostat regional yearbook 2008, General and regional statistics, Statistical books, Office for Official Publications of the European Communities, Luxembourg, 2008, Internet, https:/ / ec.europa.eu/eurostat/documents/3217494/5692801/KS-HA-08-001-EN.PDF/e77 da79e-a9ef-4225-ba2f-20e2e33ecffd, 18/02/2021, p. 64. 
podršci sektorima za istraživanje i razvoj u preduzećima koja ulaze u sastav klastera; 2) Mere politike konkurencije koje su usmerene ka uspostavljanju odnosa komplementarnih i suplementarnih karakteristika između pojedinačnih preduzeća koja sačinjavaju klastere u cilju povećanja raznovrsnosti i kvaliteta njihovih proizvoda. ${ }^{22}$

Sa primenom razmatranog oblika širenja osnovnog Detroitskog klastera moglo bi da dođe do promena u organizovanju poslovnih aktivnosti $u$ posmatranim odredišnim aglomeracijama proizvodnje, što bi direktno uticalo na strukturne promene u privredama posmatranih zemalja. Na taj način bi se omogućio i brži transfer tehničkih, naučnotehnoloških, upravljačkih i organizacionih resursa i mera iz osnovnog klastera u izvedene klastere u tim aglomeracijama proizvodnje. Time se omogućava jednostavnije i brže sprovođenje procesa širenja klastera, što bi indirektno moglo da utiče na strukturne promene u privredama tih zemalja. ${ }^{23}$

Posebnost aglomeracija proizvodnje, u kojima posluju klasteri, ispoljava se $u$ tome što one predstavljaju zatvorene privredne sisteme $u$ kojima dolazi do ubrzanja obavljanja poslovnih aktivnosti u odnosu na standardne oblike organizovanja poslovanja. Samim time, primenom mera politike tržišta rada i politike kapitala u takvim privrednim sistemima, u kojima je omogućena veća mobilnost faktora proizvodnje, kao što su posmatrane aglomeracije proizvodnje, skraćuje se vreme potrebno za efektuiranje tih mera. ${ }^{24}$

Uz postojanje pretpostavke o konstantnoj produktivnosti rada to dovodi do bržeg smanjenja nezaposlenosti $\mathrm{u}$ kratkom roku, a u skladu sa prihvatanjem osnovne hipoteze ovog rada, utiče i na brži porast BDP-a $u$ dugom roku.

$\mathrm{Na}$ ovakav način prouzrokovane strukturne promene $\mathrm{u}$ posmatranim privredama takođe mogu da imaju za posledicu i povratan pozitivan uticaj

${ }^{22}$ Eurostat, Eurostat regional yearbook 2015, General and regional statistics, Statistical books, Publications Office of the European Union, Luxembourg, 2015, Internet, https:/ / ec.europa. eu/eurostat/documents/3217494/7018888/KS-HA-15-001-EN-N.pdf/6f0d4095-5e7a-4aabaf28-d255e2bcb395, 26/01/2021, p. 140.

${ }^{23}$ Marco Marchese \& Akiko Sakamoto, Skills development for industrial clusters: a preliminary review, Employment Working Paper No. 8, International Labour Organization, International Labour Office, Skills and Employability Department, Employment Sector, Geneva, 2008, Internet, https://www.ilo.org/wcmsp5/groups/public/ --ed_emp/ --ifp_skills/documents/ publication/wcms_103624.pdf, 21/03/2021, p. 5.

${ }^{24}$ World Bank, Industry Competitiveness and Jobs, An Evaluation of World Bank Group Industry-Specific Support to Promote Industry Competitiveness and Its Implications for Jobs, An Independent Evaluation, International Bank for Reconstruction and Development /The World Bank, 2017, Internet, https://openknowledge.worldbank.org/bitstream / handle/10986/25294/109333-WP-PUBLIC.pdf?sequence=5\&isAllowed=y, 22/12/2020, 80 p. 85. 
usmeren na poslovanje upravo tih aglomeracija proizvodnje i klastera koji se nalaze u njima tokom budućih vremenskih perioda. ${ }^{25}$

Posledice strukturnih promena takođe se mogu posmatrati sa stanovišta inostranih privreda. Širenje klastera u inostrane zemlje predstavlja i način da se pravno dozvoljenim sredstvima uvezu savremeni tehnički i tehnološki, kao i upravljački i organizacioni sistemi poslovanja, koji će direktno pozitivno uticati na upošljavanje industrijskih kapaciteta i radne snage te zemlje. To će uticati na strukturne promene u tim inostranim privredama.

$S$ jedne strane, na taj način dolazi do usaglašavanja pravila poslovanja zemlje iz koje dolazi transplant klaster sa inostranim pravilima zemlje u kojoj se nalazi odredišna aglomeracija proizvodnje.

Sa druge strane, na taj način se realizuje i mogućnost da se prilikom formiranja novih izvedenih klastera utiče i na međusobno usaglašavanje pravila sa drugim klasterima koji već posluju u toj inostranoj zemlji.

\section{Zaključak}

U ovom radu izvršena je analiza uticaja potencijalnog širenja klastera na strukturne promene u privredama SAD i EU tokom ukupnog posmatranog perioda od 2006. do 2018. godine. Tokom tog perioda, Svetska ekonomska kriza iz 2007. godine imala je dodatan negativan uticaj na privrede posmatranih zemalja.

Istraživanje sadržano u ovom radu sprovedeno je posebno na primerima aglomeracija i klastera iz oblasti automobilske industrije u privredama SAD i EU. To je izvršeno u cilju pronalaženja dodatnih predloga mera različitih ekonomskih politika pomoću kojih bi se uticalo na širenje klastera, kao načina za poboljšanje efikasnosti privreda posmatranih zemalja.

Rezultati istraživanja sprovedenog u ovom radu pokazuju sledeće:

- U prvom delu rada prikazan je uticaj posmatranog oblika širenja klastera na strukturne promene u privredama. Samim time, različiti oblici širenja osnovnog klastera u domaćoj i inostranoj zemlji mogu da predstavljaju uzrok strukturnih promena u privredama tih zemalja. To se događa tako što promene u načinima poslovanja izazvane širenjem klastera na nivou urbanih aglomeracija utiču posledično i na takve promene na nivou čitavih posmatranih privreda, odnosno dovode do strukturnih promena u njima.

${ }^{25}$ European Economy, Impact of the current economic and financial crisis on potential output, Occasional Papers No. 49, European Commission, Directorate-General for Economic and Financial Affairs, June 2009, Internet, https:/ / ec.europa.eu/economy_finance/ publications /pages/publication_summary15477_en.htm, 18/02/2021, p. 36. 
- U drugom delu rada analiziran je uticaj širenja klastera na strukturne promene praćenjem odnosa kretanja nezaposlenosti i BDP-a. Odnosi ovih ekonomskih veličina predstavljeni su posredstvom Okunovog koeficijenta. Dobijene vrednosti $u$ posmatranim urbanim aglomeracijama, i saveznim državama u kojima se nalaze njihova sedišta, pokazale su statistički značajna odstupanja od njegove standardne vrednosti. Na osnovu dobijenih rezultata može se zaključiti da je potrebno pristupiti procesu širenja osnovnog Detroitskog klastera, kako u SAD kao domaćoj zemlji tako i u Velikoj Britaniji i Francuskoj, kao posmatranim inostranim zemljama u kojima bi mogla da se nalaze sedišta potencijalnih odredišnih urbanih aglomeracija.

- U trećem delu rada prikazane su posledice razmatranih strukturnih promena u privredama domaćih i inostranih zemalja. Posledice u privredama domaćih zemlja obuhvataju: (1) posledice po prostorno razmeštanje i grupisanje privrednih subjekata na određenim lokacijama, čime dolazi upravo do uticaja na poslovanje klastera u aglomeracijama proizvodnje, i (2) posledice po funkcionalni raspored poslovnih aktivnosti koje ti privredni subjekti obavljaju, čime dolazi do diversifikacije i specijalizacije proizvodnje u pojedinačnim preduzećima koja sačinjavaju posmatrane klastere. Posledice $u$ inostranoj zemlji obuhvataju: (1) usaglašavanje pravnih i poslovnih pravila potrebnih za funkcionisanje klastera; (2) uspostavljanje međunarodne saradnje posebno iz oblasti istraživanja i razvoja; (3) organizovanje ukupne proizvodnje u klasterima, i (4) povećanje sredstava za finansiranje različitih oblika strukturnih ekonomskih politika u inostranoj zemlji. $\mathrm{Na}$ taj način bi mogao da se realizuje međusoban uticaj domaćih $i$ inostranih privreda, u skladu sa širenjem osnovnog klastera i njegovom povezanošću sa novim izvedenim ili postojećim konkurentskim klasterima u inostranoj zemlji.

Implikacije istraživanja sprovedenog u ovom radu se mogu svrstati kao:

- Teorijske implikacije ispoljavaju se kroz uticaj na koncepte budućih makroekonomskih politika, formulisanjem predloga dodatnih mera strukturne ekonomske politike. Ove dodatne mere strukturne ekonomske politike mogu da budu posebno usmerene na industrijske kapacitete i radnu snagu, s jedne strane, odnosno tehnologiju i konkurentnost preduzeća u klasterima, s druge strane. Na taj način se utiče na kreiranje koncepata makroekonomskih politika usmerenih na procese stvaranja i održanja organizacije poslovanja posredstvom klastera u aglomeracijama proizvodnje.

- Praktične implikacije ispoljavaju se kroz potrebu za usvajanjem pravnih i privrednih normi koje omogućavaju nesmetano formiranje i funkcionisanje aglomeracija proizvodnje i klastera koji se nalaze u njima. 
Osnovni doprinos ovog rada predstavlja isticanje značaja klastera kao načina organizovanja poslovnih aktivnosti u privredama, potrebe za primenom razmatranih oblika širenja klastera u privredama SAD i EU, kao i važnosti sadejstva primene tih oblika širenja klastera sa primenom razmatranih dodatnih strukturnih mera ekonomske politike.

Mere tekuće i strukturne ekonomske politike, koje su primenjene $u$ urbanim aglomeracijama $\mathrm{u}$ posmatranim periodima, jesu uticale na smanjenje kratkoročne nezaposlenosti. Upravo zbog posebne organizacije poslovanja u urbanim aglomeracijama, i klasterima koji se nalaze u njima, došlo je do brže i bolje iskorišćenosti tih mera, a time i do povećanja BDP-a. $\mathrm{Na}$ osnovu toga se može konstatovati da se osnovna hipoteza ovog rada može prihvatiti kao tačna.

Shodno tome, može se konstatovati i da organizacija poslovanja u obliku klastera u aglomeracijama proizvodnje predstavlja odovarajući način za potencijalno povećanje efikasnosti iskorišćavanja industrijskih kapaciteta i upotrebe radne snage $u$ razmatranom sektoru automobilske industrije. Iz tih razloga je potrebno da vlade država primenjuju dodatne mere svoje strukturne ekonomske politike i na taj način usmeravaju svoju ukupnu ekonomsku politiku ka širenju klastera, kako u domaćim privredama tako i u privredama inostranih zemalja.

\section{Bibliografija}

Ball, Laurence, Leigh, Daniel \& Loungani, Prakash, Okun's Law: Fit at 50?, IMF Working Paper, WP/13/10, International Monetary Fund, Research Department, January 2013, Internet, https://www.imf.org/en/ Publications/WP/Issues/2016/12/31/Okun-s-Law-Fit-at-50-40236, 29/08/2020.

Bergman, Edward M., \& Feser, Edward J., Industrial and Regional Clusters: Concepts and Comparative Applications, (1999). Reprint, Edited by Scott Loveridge and Randall Jackson, WVU Research Repository, 2020.

Bureau of Economic Analysis, Gross Domestic Product by Metropolitan Area, 2017, News Release, BEA 18-46, U.S. Department of Commerce, Washington D.C., USA, 18 September 2018. Internet, https://www.bea. gov/system/files/2018-09/gdp_metro0918_0.pdf, 12/12/2020.

Bureau of Labor Statistics, Metropolitan Area Employment and Unemployment - May 2020, News Release, USDL-20-1309, U.S. Department of Labor, Washington D.C., USA, 1 July 2020, Internet, http://www.bls.gov/ news.release/archives/srgune_02262016.pdf, 15/12/2020.

European Economy, Impact of the current economic and financial crisis on potential output, Occasional Papers No. 49, European Commission, Directorate-General for Economic and Financial Affairs, June 2009, 
Internet, https://ec.europa.eu/economy_finance/publications/pages/ publication_summary15477_en.htm18/02/2021.

European Economy, The EU's response to support the real economy during the economic crisis: An overview of Member States' recovery measures, Occasional Papers No 51, European Commission, Directorate-General for Economic and Financial Affairs, July 2009, Internet, https://ec.europa.eu/ economy_finance/publications/pages/publication_summary15670_en. htm19/02/2021.

Eurostat, Eurostat regional yearbook 2008, General and regional statistics, Statistical books, Office for Official Publications of the European Communities, Luxembourg, 2008, Internet, https://ec.europa.eu/ eurostat/documents/3217494/5692801/KS-HA-08-001-EN.PDF/e77da 79e-a9ef-4225-ba2f-20e2e33ecffd, 18/02/2021.

Eurostat, Eurostat regional yearbook 2015, General and regional statistics, Statistical books, Publications Office of the European Union, Luxembourg, 2015, Internet, https:/ /ec.europa.eu/ eurostat/documents /3217494/7018888/KS-HA-15-001-EN-N.pdf/6f0d4095-5e7a-4aab-af28d255e2bcb395, 26/01/2021.

Federal Reserve, Industrial Production and Capacity Utilization, Statistical release, G.17 (419), Board of Governors of The Federal Reserve System, Washington D.C., USA, 15 December 2020, Internet, https:// www.federalreserve.gov/releases/G17/20201215/g17.pdf, 14/04/2021.

Gama, André, Saget, Catherine \& Eyraud, François, Inventory of labour market policy measures in the EU 2008-13: The crisis and beyond, Synthesis Report, International Labour Organization, International Labour Office, Research Department, Geneva, 2015, Internet, https://www.ilo.org/wcmsp5/ groups/public/ --dgreports/ --inst/documents/publication/wcms_ 436119.pdf, 15/04/2021.

Gnjatović, Dragana, Osnovi makroekonomije, Megatrend univerzitet primenjenih nauka, Beograd, 2003.

Grbić, Vladimir, Ekonomija Evropske unije, Megatrend univerzitet primenjenih nauka, Beograd, 2005.

ILO, The future of work in the automotive industry: The need to invest in people's capabilities and decent and sustainable work, Issues paper for the Technical Meeting on the Future of Work in the Automotive Industry, (Geneva, 15-19 February 2021), TMFWAI/2021, International Labour Organization, Sectoral Policies Department, Geneva, 2020, Internet, https://www.ilo.org/wcmsp5/groups/public/ --ed_dialogue/ - sector/documents/meetingdocument/wcms_741659.pdf, 19/03/2021.

Marchese, Marco \& Sakamoto, Akiko, Skills development for industrial clusters: a preliminary review, Employment Working Paper No. 8, International 
Labour Organization, International Labour Office, Skills and Employability Department, Employment Sector,

Geneva, 2008, Internet, https://www.ilo.org/wcmsp5/groups/public/ -ed_emp/ - -ifp_skills/documents/publication/wcms_103624.pdf, $21 / 03 / 2021$.

Nallari, Raj \& Griffith, Breda, Clusters of Competitiveness, Directions in Development, Private Sector Development, International Bank for Reconstruction and Development / The World Bank, Washington D.C., 2013, Internet, https://openknowledge.worldbank.org/bitstream/ handle/10986/15788/798920PUB0Clus00Box377374B00PUBLIC0.pdf?se quence=1\&isAllowed=y, 24/11/2020.

Nallari, Raj, Griffith, Breda \& Yusuf Shahid, Geography of Growth: Spatial Economics and Competitiveness, Directions in development, Infrastructure, 68360, International Bank for Reconstruction and Development / The World Bank, 2012, Internet, https:/ / openknowledge.worldbank.org/ bitstream/handle/10986/6020/683600PUB0EPI0067902B0978082139486 1.pdf? sequence $=1 \&$ isAllowed $=\mathrm{y}, 15 / 01 / 2021$.

OECD (2014), OECD Economic Surveys: United States 2014, OECD Publishing, Paris, june 2014, Internet, https:/ / dx.doi.org/10.1787/eco_surveys-usa2014-en, 11/04/2021.

OECD (2015), OECD Economic Surveys: United Kingdom 2015, OECD Publishing, Paris, february 2015, Internet, https://dx.doi.org/10.1787/ eco_surveys-gbr-2015-en, 17/04/2021.

OECD (2015), OECD Economic Surveys: France 2015, OECD Publishing, Paris, march 2015, Internet, http://dx.doi.org/10.1787/eco_surveys-fra-2015en, $27 / 04 / 2021$.

Snowdon, Brian \& Vane, Howard R, Modern macroeconomics, Its origin, development and current state, Edward Elgar, Cheltenham, UK Northampton, MA, USA, 2005.

World Bank, Industry Competitiveness and Jobs, An Evaluation of World Bank Group Industry-Specific Support to Promote Industry Competitiveness and Its Implications for Jobs, An Independent Evaluation, International Bank for Reconstruction and Development/The World Bank, 2017, Internet, https:/ / openknowledge.worldbank.org/bitstream/handle/ 10986/25294/109333-WP-PUBLIC.pdf? sequence=5\&isAllowed=y, $22 / 12 / 2020$.

Internet stranice

https://www.bea.gov/data/gdp/gdp-county-metro-and-other-areas, 14/02/2021.

https://www.bls.gov/bls/news-release/metro.htm, 16/02/2021. 
https://www.census.gov/ programs-surveys/metro-micro/about.html, 16/04/2021.

https://stats.oecd.org/index.aspx?queryid=60702\#, 02/04/2021.

\title{
STRUCTURAL CHANGES IN THE US AND EU ECONOMIES CAUSED BY EXPANDING OF CLUSTERS
}

\begin{abstract}
In the long run, the usage of economic policy measures in the US and EU economies to overcome the consequences of the 2007 global economic crisis has produced different results in different urban agglomerations. In order to perceive the causes of such effects of the measures applied, this paper conducts analyses of the functioning of urban agglomerations, with a focus on specific forms of cluster expansion that are located within them. This is done primarily through the intermediary of two basic economic aggregates, unemployment and GDP, whose changes are monitored during the observed periods. The influence of the potential expanding of the basic cluster in them on economic aggregates is examined, and their mutual relation is observed according to the basic hypothesis of this paper. Based on the given results, suggestions for additional measures of structural economic policy are formed.
\end{abstract}

Key words: industrial clusters, Okun's coefficient, structural economic policy, expanding of clusters. 